\title{
The Metaphor in the Grammaticalization Process of the Verb DANAR to Express Inceptive Aspect with Extension of the Action in Brazilian Portuguese ${ }^{1}$
}

\section{A metáfora no processo de gramaticalização do verbo DANAR para expressão do aspecto inceptivo com prolongamento da ação no português brasileiro}

Thaís Franco de Paula*

Universidade do Estado de Minas Gerais

Divinópolis - Minas Gerais / Brasil

Sueli Maria Coelho**

Universidade Federal de Minas Gerais

Belo Horizonte - Minas Gerais / Brasil

\begin{abstract}
RESUMO: Este trabalho tem o objetivo de apresentar como a metáfora atua no processo de gramaticalização do verbo DANAR, que passa de verbo lexical pleno a verbo gramatical, auxiliar, em construções do tipo: "A criança danou (se) a chorar", aqui chamada de $\mathrm{V} 1_{\text {DANAR }}+$ (pron) + (prep) + V2 $2_{\text {infinitivo. }}$ Acredita-se que esse novo uso de DANAR, para marcar o aspecto inceptivo com prolongamento da ação, seja consequência de um processo metafórico cognitivo que envolve os esquemas imagéticos movimento e força, os quais já se encontravam subjacentes em DANAR concreto, o que justifica que esse verbo, não prototípico para marcação de aspecto, possa ter atualizado essa categoria gramatical.
\end{abstract}

PALAVRAS-CHAVE: Verbo DANAR. Gramaticalização; Metáfora; Aspecto verbal.

* thaisfrancodepaula@yahoo.com.br

**su.coelho@uol.com.br

${ }^{1}$ The reflections presented in this paper are the result of an wider research on the grammaticalization of the verb danar as an aspect marker in Brazilian Portuguese carried out to be part of the master's degree thesis entitled Study of the grammaticalization process of the verb Danar to mark aspect in Brazilian Portuguese presented to the Graduate Program in Linguistic Studies of the Universidade Federal de Minas Gerais. 


\begin{abstract}
This paper aims to present how a metaphor acts in the grammaticalization process of the verb $D A N A R$, from Brazilian Portuguese, ranging from the full lexical verb to the grammatical, auxiliary verb in constructions like: "The kid danou(-se) to cry", hereby referred to as V1 $1_{\text {DANAR }}+$ (pron) $+($ prep $)+\mathrm{V} 2$ infinitive . We support that this new usage of $D A N A R$, perceived as a marker of an inceptive aspect with an extension of action, is a consequence of a metaphorical cognitive process that involves imagetic schemes of motion and force, which already existed within the concrete form of DANAR, which justifies that this verb, although not the archetypal aspect marker, may have updated this grammatical category.
\end{abstract}

KEYWORDS: “DANAR” verb. Grammaticalization; Metaphor; Verbal aspect.

\title{
1 Initial considerations
}

According to Lakoff and Johnson (2002), metaphor is, contrary to what most people believe, more than a resource of poetic imagination and a rhetorical ornament. According to authors, "metaphor is infiltrated in daily life, not only in language, but also in thinking and in action. Our ordinary conceptual system, in terms of which we do not only think, but also act on, is fundamentally metaphorical" (LAKOFF \& JOHNSON, 2002, p. 45). This work intends to demonstrate that metaphor is not infiltrated in language alone, but also influences the production of language, as well as the choice of linguistic resources to express a certain grammatical category. We intend to demonstrate how metaphor acts in the elaboration of a grammatical construction $^{2}$ that appears in $20^{\text {th }}$-century Brazilian Portuguese to express the grammatical category of "aspect". For this purpose, we will use the verb $D A N A R$ as the core object.

\footnotetext{
${ }^{2}$ Verbal periphrases are some of the resources of aspect marking. However, as we have verified in several works on grammaticalization presented by Gonçalves et al. (2007), grammaticalization can reach structures that are larger than an item and smaller than a clause. We believe that the process of change that affected the item DANAR to mark "aspect" has not influenced it alone, but also the other elements that are part of its syntagmatic relations. That being said, we conceive grammaticalization in a broader manner, similar to Bybee (2003, p. 602): "The recent literature on grammaticization seems to agree that it is not enough to define grammaticization as the process by which a lexical item becomes a grammatical morpheme, but rather it is important to say that this process occurs in the context of a particular construction (...). In fact, it may be more accurate to say that a construction with particular lexical items in it becomes grammaticized, instead of saying that a lexical item becomes grammaticized."
} 
The verb DANAR has been used in Brazilian Portuguese in the construction $\mathrm{V} 1_{\text {DANAR }}+$ (pron) + (prep) + $\mathrm{V} 2_{\text {infinitivo }}$ to mark the grammatical category of "aspect", as in the following example:

(1) d (@gmzmofa). "cara eu e minha mae somos as mais animadas da festa a gnt dana canta." $31 \mathrm{Dez} 2012,7: 53$ p.m. Tweet.

(1) “"Man, my mom and I are the most enthusiastic people in the party; we started singing and we couldn't stop." ${ }^{4}$ (bold added, translated by the author).

\section{In}

(2) "Compete ao tribunal danar o réu" (HOUAISS, 2001).

(2) "It is the court's job convict the defendant." (HOUAISS, 2001, translated by the author);

(3) "Ler no escuro pode danar a vista" (HOUAISS, 2001).

(3) "Reading in the dark can harm your sight" (HOUAISS, 2001, translated by the author); and 2001).

(4) "Um cão contaminado pode danar uma pessoa" (HOUAISS,

(4) "An infected dog can harm a person" (HOUAISS, 2001, translated by the author)

The verb DANAR is used with a lexical function, and, according to Houaiss (2001), bears the meanings of (2) convict judicially; (3) cause or suffer damage, loss, or injury; and (4) become hydrophobic. The function

\footnotetext{
${ }^{3}$ See Paula (2014)

${ }^{4}$ It is important to note that the linguistic phenomenon described in this study is peculiar to the Portuguese language and thus the attempt to translate all the examples into English is only approximate and cannot fully express the semantic load that the construction has in the Portuguese language.
} 
of DANAR in examples (2) to (4) differs substantially from the function performed by the same verb in example (1) and in the following sentences:

(5) "A criança danou a chorar" (HOUAISS, 2001).

(5) "Child started crying and kept crying a lot." (HOUAISS, 2001, translated by the author)

(6) "Com a música, danou-se a dançar" (HOUAISS, 2001).

(6) "Hearing the song, he began to dance on and on to the music" (HOUAISS, 2001, translated by the author);

In (1), (5), and (6), the verb DANAR joins another verb in the infinitive form (optionally appearing a pronoun and a preposition between them $^{5}$ ), to take on a grammatical function: it loses notional content and goes on to mark the verbal category of "aspect", which has the function of delimiting the internal temporal constituency. According to Comrie (1976), "aspects are different ways of viewing the internal temporal constituency of a situation" (COMRIE, 1976, p. 3). Comrie (ibid.) also distinguishes between tense and aspect, claiming that tense is a time external to the situation, while aspect characterizes the internal temporal structure of the event. Hence, tense is a deictic category, but aspect is not.

Thus, in (1), for example, DANAR marks the internal temporal constituency of singing, expressing that the action of singing has a certain duration.

A diachronic analysis, from the 19th Century to the 21st Century, has revealed that this verb has undergone a grammaticalization process and has begun to perform the function of an inceptive aspect marker with an extension of the action, from the 20th century on. DANAR marks that the action expressed by V2 has begun and has lasted in time. Thus, example (5) conveys not only that the child has started to cry, but also that the action of crying has begun and has lasted for a period of time.

This paper aims to demonstrate that the possibility of DANAR, a non-archetypal verb to mark "aspect", expressing this grammatical category

${ }^{5}$ For more details relating to the elements that compose the construction $\mathrm{V} 1_{\text {DANAR }}+$ (pron) $+($ prep $)+V 2_{\text {infinitive }}$, see also Paula (2014) 
is the consequence of a metaphorical cognitive process, which involves the imagetic schemes of motion and force, which were already subjacent to the concrete form of $D A N A R$, as seen below.

\section{The metaphor: a cognitive mechanism acting on grammaticalization}

In the grammaticalization processes, in our conception, metaphor is related to the desemanticization and the abstraction of items ranging from a lexical to a grammatical domain or of items ranging from a less grammatical to a more grammatical domain.

This passing from more concrete usages to more abstract usages is the cognitive process of meaning extension, which has been called metaphor in the definition of Oliveira (2001, p.36; translated by authors): "a cognitive process that allows us to map schemes, learned directly by our body, in more abstract domains, whose experimentation is indirect.'

This cognitive process is, to many semanticists, responsible for the elaboration of meaning, which, according to these scholars, is not merely linguistic, but also cognitive. They believe that the speaker acquires the semantic properties of language from concrete experiences, which are metaphorically extended to map more abstract domains. According to Lakoff (1987), a great part of our experience is structured metaphorically by means of a smaller number of schemes, which derive from our bodily human experiences. In this paper, we also defend this position, as the polysemy ${ }^{6}$ of $D A N A R$ is here considered to be the result of conceptual metaphors of motion and force, which are bodily based.

The meaning of $D A N A R$, for example, was initially related to the physical domain ${ }^{7}$, but, throughout the history of the language, it began to

\footnotetext{
${ }^{6}$ We are adopting the idea that polysemy results from a semantic process by which a basic meaning gives rise to derived meanings. These new meanings are obtained by transposing a sense of a more concrete source domain to a more abstract target domain. For Kövecses (2010, p. 251), "polysemy involves words that have a number of related senses (as opposed to homonymy where the senses are completely unrelated). This is the traditional definition of polysemy that cognitive linguists also accept".

${ }^{7}$ One example of DANAR related to the physical domain is found in our corpus from the 19th Century: "(...) everything had been crammed in there, to hurt, to danar, to crush." (CORPUS DO PORTUGUÊS, emphasis added, translated by the author). “(...) tudo fora metido ali, para ferir, para danar, para moer." (CORPUS DO PORTUGUÊS, grifo nosso)
} 
relate to the abstract domain of grammar as well, to mark verbal categories, such as time, aspect, number, person, and tense.

\section{Methodology}

To undertake the research that resulted in the considerations presented herein, the present study used the Corpus do Português database, built and maintained by Mark Davies (Brigham Young University) and Michael J. Ferreira (Georgetown University). This database is available online at http:// www.corpusdoportugues.org and contains over 45 million words from nearly 57 thousand texts written in Portuguese, dated from the 13th Century to the 20th. In this corpus, occurrences of the verb DANAR are identified only from the 19th Century on, which justifies the temporal selection of this research to begin in this period. This website's search tool was employed to compose this study's diachronic corpus, containing lexical and grammatical forms of the verb DANAR. However, the most recent texts contained in the Corpus do Português date from the 20th Century. Given that our starting point was the hypothesis that the verb $D A N A R$ becomes more grammatical ${ }^{8}$ in the 21 st Century, as it could be verified that the construction it composes is more typical of informal oral contexts, the social network Twitter was chosen as a source of data, within which written records with traces of informal orality could be found.

After having selected all the forms of DANAR from the corpora, we proceeded to the analysis of the meaning that the item takes on in each occurrence in order to verify the polysemy of the item, one of the signs of the grammaticalization of the verb.

In this stage of the research, we found that beneath all the senses of the verb $D A N A R$ lie the imagetic schemes of motion and force, which will be described in the next section.

\footnotetext{
${ }^{8}$ From a cognitive linguistic point of view, an item (in this specific case study, the verb) becomes more grammatical as it becomes more abstract, a fact that allows it to incorporate grammatical functions that previously, when it was a lexical item, did not contain specific grammatical functions that are more grammatical than others. It is imporatant to remember that there is a grammatical continuum here and that the functions that are more to the left of the continuum are less grammatical than those to the right.
} 


\section{Presentation and discussion of results}

For the verb DANAR to perform the function of expressing the inceptive aspect with extension of the verbal action, it is our contention that this verb has undergone a metaphorical process of semantic abstraction, which produced the abstraction of the more concrete senses of the verb until it reached its given grammatical usage. According to Sigiliano (2012), the cognitive motivation to employ non-archetypal auxiliary verbs (V1) in inceptive constructions is the metaphor of motion. This metaphor comes from the so-called imagetic schemes (or image schemes) that are in fact sensorimotor schemes, which emerge from the interaction between body and environment, and are responsible for many of our expressions. According to cognitive semantic principles (cf. LAKOFF, 1987), the concepts, as opposed to an objectivist sense of meaning, are built by the interaction between body, mind, and experiences in the world. In this paradigm, the meaning emerges from experiences those human bodies have in their interaction with the environment that surrounds them. Through these experiments, relatively simple images (path, strength, balance, container) that arise in our everyday bodily experience schemes are designed as entry-level categories that anchor the meaning of our linguistic expressions. For Evans \& Green (2006, p. 45), "the idea that experience is embodied entails that we have a species-specific view of the world due to the unique nature of our physical bodies. In other words, our construal of reality is likely to be mediated in large measure by the nature of our bodies." For Gibbs Jr. \& Metlock (2008, p. 164), "psycholinguistic studies demonstrate that people's understanding of linguistic descriptions of action mentally simulate the action. As such, there is significant psycholinguistic evidence consistent with the broad claim that language use is closely tied to embodied imagination." Sigiliano (2012), analyzing a vast number of empirical uses of inceptive constructions, reveals that the verbs that take the $\mathrm{V} 1$ position, when in their full use, share the notion of motion. Amongst the analyses of Sigiliano (2012), one can find the analysis of a construction with $D A N A R$. The present work takes further step in defending that the construction with DANAR marks not only inceptivity, as Sigiliano $(2012)$ has proposed, but also cumulates the inceptive and durative aspects, since DANAR indicates that the action expressed by $\mathrm{V} 2$ has begun and then lasted for a period of time. Since $V 1_{\text {DANAR }}+$ (pron) + (prep) $+\mathrm{V} 2_{\text {infinitive }}$ involves more than one aspectual notion (inceptivity + extension of verbal action [duration]), we therefore argue that the cognitive motivation 
to employ this construction as a marker of these aspects is connected to the metaphors, which are in turn connected to more than one imagetic scheme. These schemes are, respectively, motion and force.

It is also our contention that these metaphors already existed in the concrete senses of $D A N A R$, which will be demonstrated next, and are therefore semantic residues of the concrete form of the verb, illustrating the persistence principle formulated by Hopper (1991). According to this principle, when a form is subject to grammaticalization, some vestiges of its original history can reflect upon its grammatical distribution.

The metaphors believed to be related to DANAR are as follows:

a) "Change is motion" (KÖVECSES, p. 370, 2010).

b) “Causes are forces" (KÖVECSES, p. 370, 2010).

The next section seeks to analyze the presence of theses metaphors in the two oldest and most frequent concrete senses found in the corpus of this research to demonstrate the phenomenon of semantic persistence, as supported in this paper.

In relation to the concrete sense (i) to ruin, contained in the following excerpt:

(7) "Horrível profanação! Escândalo inaudito, e que podia danar um cartório sempre conceituado entre os mais graves!” (CORPUS DO PORTUGUÊS, século XIX, grifo nosso).

(7) "Dreadful desecration! Unheard of scandal, and one that could ruin a notary's office that had always been deemed amongst the most earnest" (CORPUS DO PORTUGUÊS, 19th Century, emphasis added, translated by the author ).

A dreadful desecration or an unheard of scandal, are causes (forces) that could damage/injure the good fame of the notary's office. It can therefore be concluded that, if there is damage, there is change in the notary's office (motion).

As for the concrete sense (ii) to irritate: 
(8) "Passou a hora do almoço, chegou a hora do jantar, entraram e saíram marinheiros, a sineta badalou novas baixas, tocou meio-dia, e nada! nem sinal de Aleixo, nem sombra dele! - Era mesmo para uma pessoa danar! Se não quisesse ir, dissesse!" (CORPUS DO PORTUGUÊS, século XX, grifo nosso).

(8) "Lunchtime passed, dinnertime came, sailors came and went, the bells rang again, midday, and nothing! No sign of Aleixo, not even his shadow! - it was really something to make someone angry! If you don't want to come, just say it! (CORPUS DO PORTUGUÊS, 20th Century, emphasis added, translated by the author).

Once can see that Aleixo's not showing up is the cause (force) that makes the person danada/irritated. The irritation provokes a change in the person's state (motion), from calm to angry.

These underlying imagetic schemes and conceptual metaphors, existing in the concrete senses of DANAR, also present themselves in the grammatical construction $\mathrm{V} 1_{\text {DANAR }}+($ pron $)+($ prep $)+V 2_{\text {infinitive }}$. Hence, it can be said that these schemes, which are already subjacent to the concrete $D A N A R$, are responsible for allowing this verb, though it is a non-archetypal aspect marker, to update this grammatical category.

This can also be seen in grammatical contexts, such as in:

(9) Tavares, Luíza (@Luizatavars). “fui abrir o portão da rosimar e fui me torcendo toda ela até assustou e danou a rir, cólica não é de Deus vei”. 10 Jan 2013, 10:16 p.m. Tweet.

(9) Tavares, Luíza (@Luizatavars). "I set out to open rosimar’s gate and went squirming and wriggling I even scared her a little and she laughed a lot, cramps are ungodlyl man”. 10 Jan 2013, 10:16 p.m. Tweet. (emphasis added, translated by the author).

The notions of motion and force are more abstract. One can even think: "but where are the notions of motion and force in this context?" A clue to the answer to this question lies in the classic metaphor "time is space" (LAKOFF \& JOHNSON, 2002), which implies that displacement in space is displacement through time. Thus, it is possible to perceive the notion of 
motion in the grammatical sense of $D A N A R$, which marks the beginning of the displacement/movement of the action through time, metaphorized as space. This metaphorical relation between time and space is also proposed by Heine et al. (1991) in the following cline, which represents the continuum of metaphorical expansion:

\section{PERSON > OBJECT > ACTIVITY > SPACE > TIME > QUALITY}

But how can one analyze the notion of force? The adoption of this imagetic scheme allows us to bring a contribution from the work of Travaglia (2010) into the present study. In his work, the linguist asserts that $D A N A R$ marks the inceptive aspect and places this verb in the roll of the contenders $^{9}$ against the verb começar (begin), prototypically inceptive. We believe, nevertheless ${ }^{10}$, that $D A N A R$ marks more than just the inceptivity of the action. The point being made here is that the grammatical DANAR, component of the construction $V 1_{\text {DANAR }}+$ (pron) + (prep) $+\mathrm{V} 2_{\text {infinitive }}$, marks that the action has begun and lasted for a period of time, this extension of the action being possible either by duration or by iteration ${ }^{11}$. In example (9), according to our view, the person does not want to express only that the other person started to laugh, but that she started to laugh and that this action has lasted for a period of time. Ergo, besides the beginning of the action, there is a continuity of the action along the axis of time, through which this action will move, metaphorically. We believe that this extension of the action, which has not been described by Travaglia (2010), is possibly due to the notion of force, which underlies the senses of DANAR. It is expected that a motion (displacement) caused by a force would have a longer duration. In other

\footnotetext{
${ }^{9}$ We take the term contender in the Labovian sense.

${ }^{10}$ See Paula (2014).

${ }^{11}$ In "There's nothing to do in car, so I begin to take a lot of pictures LOL" (TWITTER, emphasis added, translated by the author) ("Não tem nada pra fazer aqui no carro, então dano a tirar_foto kkkk" (TWITTER, grifo nosso)), the extension of the action of taking pictures is caused by iteration. The action of taking pictures is repeated and, consequently, lasts in time. In "today it started to rain a lot when we were coming back home". (TWITTER, emphasis added, translated by the author) ("hj danou a chover quando a gente tava vindo embora". (TWITTER, grifo nosso)) the extension of action apparently is not caused by repetition, but by the duration of the rain over time or by the length of the way back home.
} 
words, it is as if the imagetic scheme of force, existing in all the senses of the lexical verb $D A N A R$, impelled and allowed the action expressed by the sentence to have a prolonged duration in time.

These cognitive questions related to the verb DANAR help also us to understand the selection of $\mathrm{V} 2$ in the construction studied here. The $\mathrm{V} 2$ inf that co-occur with $D A N A R_{\text {fin }}$ have been analyzed and classified according to the chart proposed by Sigiliano (2011) for the semantic classification of verbs. The result can be seen in the following graph:

Graph 1: Semantic types V2

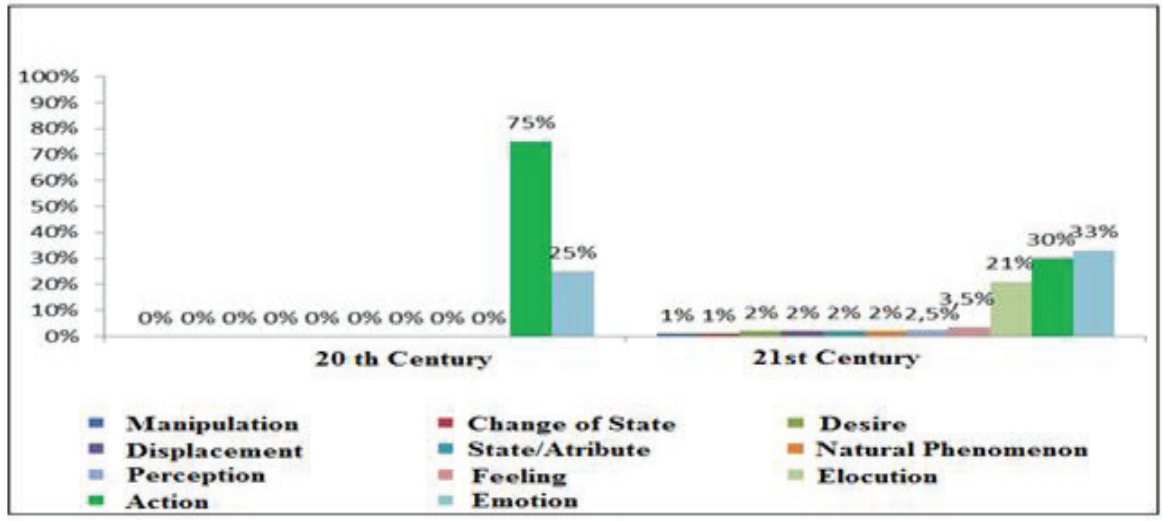

Source: Collected data

The data presented in the graph above illustrate that, in the 20th Century, as well as in the 21 st Century, action and emotion ${ }^{12}$ verbs prevail in V2, which can be explained by the metaphors (a) and (b) presented below, which are related to the cognitive schemes of motion and force subjacent to the verb $D A N A R$, as described above.

(a) "Action is motion" (KÖVECSES, 2010, p. 185, emphasis added).

(b) "Emotion is a natural force" (KÖVECSES, 2010, p. 108, emphasis added).

12 The ideia of emotion also is not well related to the concrete sense of "irritate". Irritation/anger is an emotion. 
Amongst the changes undergone by an item after the grammaticalization process, the first is related to semantic alterations. In this process of change, the item gradually loses its notional content, incorporating grammatical content and becoming more polysemic, while it begins to be used with new meanings.

For Silva (2003), polysemy is achieved when there is certain semantic coherence between the various senses of a determined form. According to this author, this coherence is determined by the imagetic schemes (resulting from perceptive and motor experiences, linked to the human body and its environment). According to Evans \& Green,

lexical items (words) typically have more than one meaning associated with them. When the meanings are related, this is called polysemy. Polysemy appears to be the norm rather than the exception in language. Lakoff proposed that lexical units like words should be treated as conceptual categories, organized with respect to an ICM or prototype. According to this point of view, polysemy arises because words are linked to a network of lexical concepts rather than to a single such concept. However, there is usually a central or 'typical' meaning that relates the others. (Evans \& Green, 2006, p. 169-170)

Sigiliano (2008), for example, supports that we stand before a case of polysemy when we deal with the several meanings of the verb pegar (catch, seize, take, get) in Brazilian Portuguese, because, in a coherent way, behind all the possible meanings of these verbs underlie the same imagetic schemes of motion and container.

The chart below presents the senses of DANAR identified in our corpus, followed by the drawings/schemes that translate the imagetic schemes of force and motion in each example. 
Chart 1: Senses of the verb DANAR identified in the corpus and their imagetic schemes

(continues)

\begin{tabular}{|c|c|c|c|c|}
\hline \multicolumn{5}{|c|}{ SENSES OF $D A N A R$} \\
\hline CLASSIFICATION & \multirow{2}{*}{$\begin{array}{l}\text { SENSE/EXAMPLE FROM } \\
\text { CORPUS/DRAWING-SCHEME }\end{array}$} & \multicolumn{3}{|c|}{ CENTURY } \\
\hline \multirow[t]{5}{*}{ CONCRETE } & & 19th & 20th & $21 \mathrm{st}$ \\
\hline & $\begin{array}{l}\text { To damage, to injure (CUNHA, } \\
\text { 2010): Woman that lost me in life } \\
\text { and death, woman who harmed me } \\
\text { in life and ruined me in death (...) } \\
\text { (translated by the author }{ }^{13} \text { ) }\end{array}$ & $\mathrm{X}$ & $\mathrm{X}$ & $\mathrm{X}$ \\
\hline & $\begin{array}{l}\text { A exerts a FORCE on } \mathrm{B} \text { that, } \\
\text { owing to this FORCE, performs a } \\
\text { MOTION (a change) of physical } \\
\text { state, emotional state, etc. } \\
\qquad \mathrm{A} \longrightarrow \mathrm{B} \longrightarrow \mathrm{B}\end{array}$ & & & \\
\hline & $\begin{array}{l}\text { To irritate (CUNHA, 2010) / But he } \\
\text { got angry in fact with the very great } \\
\text { stupid woman bringing forward his } \\
\text { dead wife, saying that he had killed } \\
\text { her from the displeasure of love for } \\
\text { certain things. (translated by the } \\
\text { author }^{14} \text { ) }\end{array}$ & $\mathrm{X}$ & $\mathrm{X}$ & $\mathrm{X}$ \\
\hline & $\begin{array}{l}\text { A exerts a FORCE on B that, } \\
\text { owing to this FORCE, performs a } \\
\text { MOTION (a change) of physical } \\
\text { state, emotional state, etc. } \\
\qquad \mathrm{A} \longrightarrow \mathrm{B}\end{array}$ & & & \\
\hline
\end{tabular}

${ }^{13}$ Mulher que me perdeste na vida e na morte, mulher que me danaste em vida e me arruinaste na morte (...) (CUNHA, 2010).

${ }^{14}$ Mas ele danou-se foi com a grandíssima da estúpida trazer pra frente a sua defunta mulher, dizendo que ele a matara de desgostos por amor de umas certas coisas. (CUNHA, 2010). 
(continues)

\begin{tabular}{|c|c|c|c|c|}
\hline \multicolumn{5}{|c|}{ SENSES OF DANAR } \\
\hline \multirow[t]{2}{*}{ CLASSIFICATION } & \multirow{2}{*}{$\begin{array}{c}\text { SENSE/EXAMPLE FROM } \\
\text { CORPUS/DRAWING-SCHEME }\end{array}$} & \multicolumn{3}{|c|}{ CENTURY } \\
\hline & & 19th & 20th & $21 \mathrm{st}$ \\
\hline \multirow[t]{4}{*}{ CONCRETE } & $\begin{array}{l}\text { To cause damage or loss; to harm, } \\
\text { to hurt./ (...) everything had been } \\
\text { put there, to hurt, to harm, to crush. } \\
\text { (translated by the author }{ }^{15} \text { ) }\end{array}$ & $\mathrm{X}$ & & \\
\hline & $\begin{array}{l}\text { A exerts a FORCE on B that, owing to } \\
\text { this FORCE, performs a MOTION } \\
\text { (a change) of physical state, emotional } \\
\text { state, etc. } \\
\text { A } \longrightarrow \text { B } \longrightarrow \text { B }\end{array}$ & & & \\
\hline & $\begin{array}{l}\text { To ruin, to spoil (BUENO, 1974)/ It } \\
\text { was too long... if we give a compliment } \\
\text { then everything gets messed up. :P } \\
\left(\text { translated by the author }{ }^{16} \text { ) }\right.\end{array}$ & & & $\mathrm{X}$ \\
\hline & $\begin{array}{l}\text { A exerts a FORCE on B that, owing to } \\
\text { this FORCE, performs a MOTION } \\
\text { (a change) of physical state, emotional } \\
\text { state, etc. } \\
\text { A } \longrightarrow \text { B } \longrightarrow \text { B }\end{array}$ & & & \\
\hline
\end{tabular}

15 (...) tudo fora metido ali, para ferir, para danar, para moer. (CORPUS DO PORTUGUÊS, século XIX, grifo nosso).

${ }^{16}$ Mendes, Le. (@djlemendes). “Tava demorando.. É só elogiar que dana tudo :P”. 09 Jan 2013, 04:24 a.m. Tweet.

${ }^{17}$ Raphael. (@ddloaf). "Aff não vejo a hora de entrar no carro e me danar pra a praia...”. 25 Dez 2012, 06:08 a.m. Tweet. 
(continues)

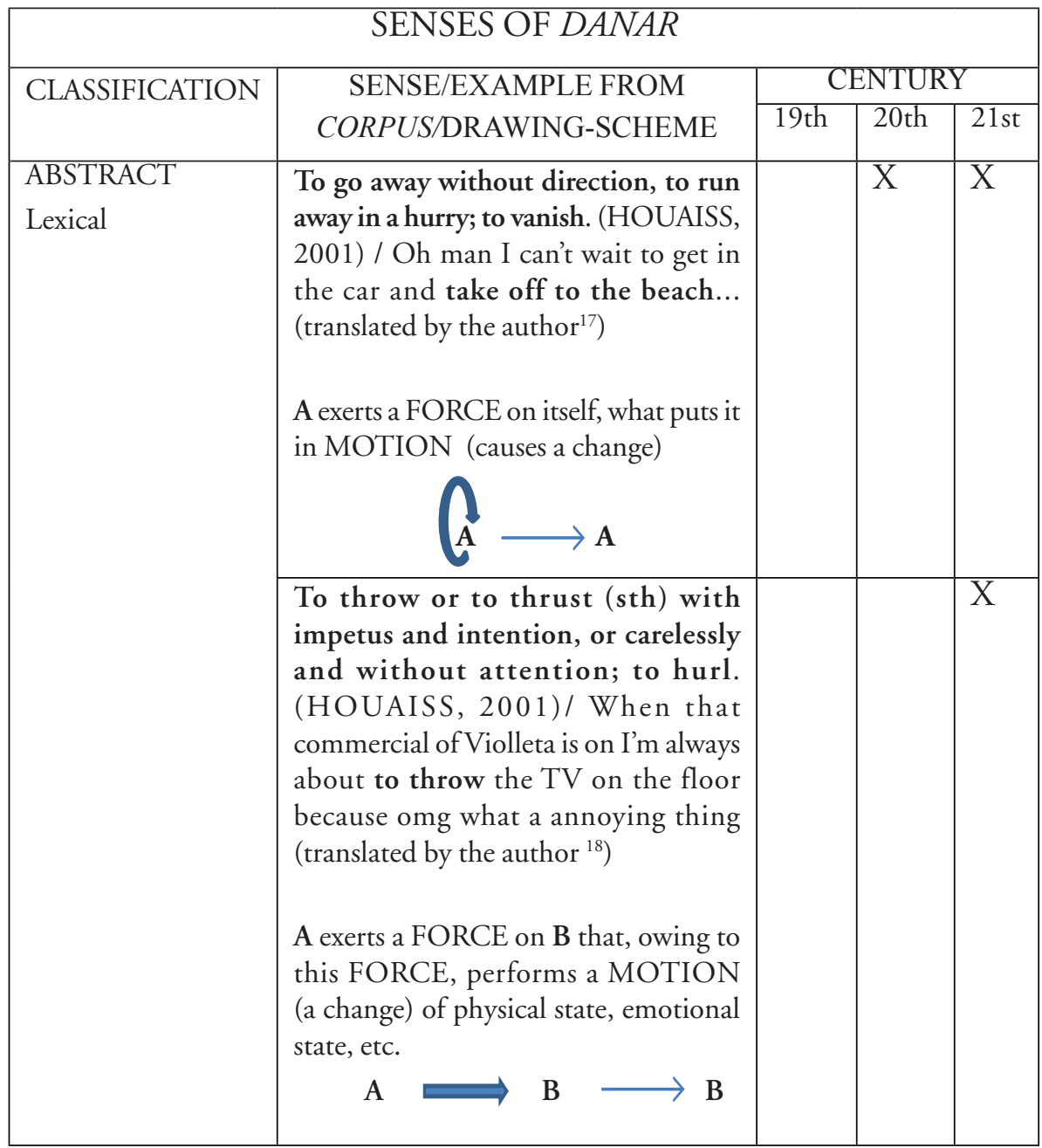

${ }^{17}$ Raphael. (@ddloaf). “Aff não vejo a hora de entrar no carro e me danar pra a praia...”. 25 Dez 2012, 06:08 a.m. Tweet.

${ }^{18}$ Paula. (@zaintheory). "Quando passa comercial de Violleta eu fico em tempo de danar a tv no chão pq ô coisa irritante”. 28 Dez 2012, 07: 53 p.m. Tweet. 
(continues)

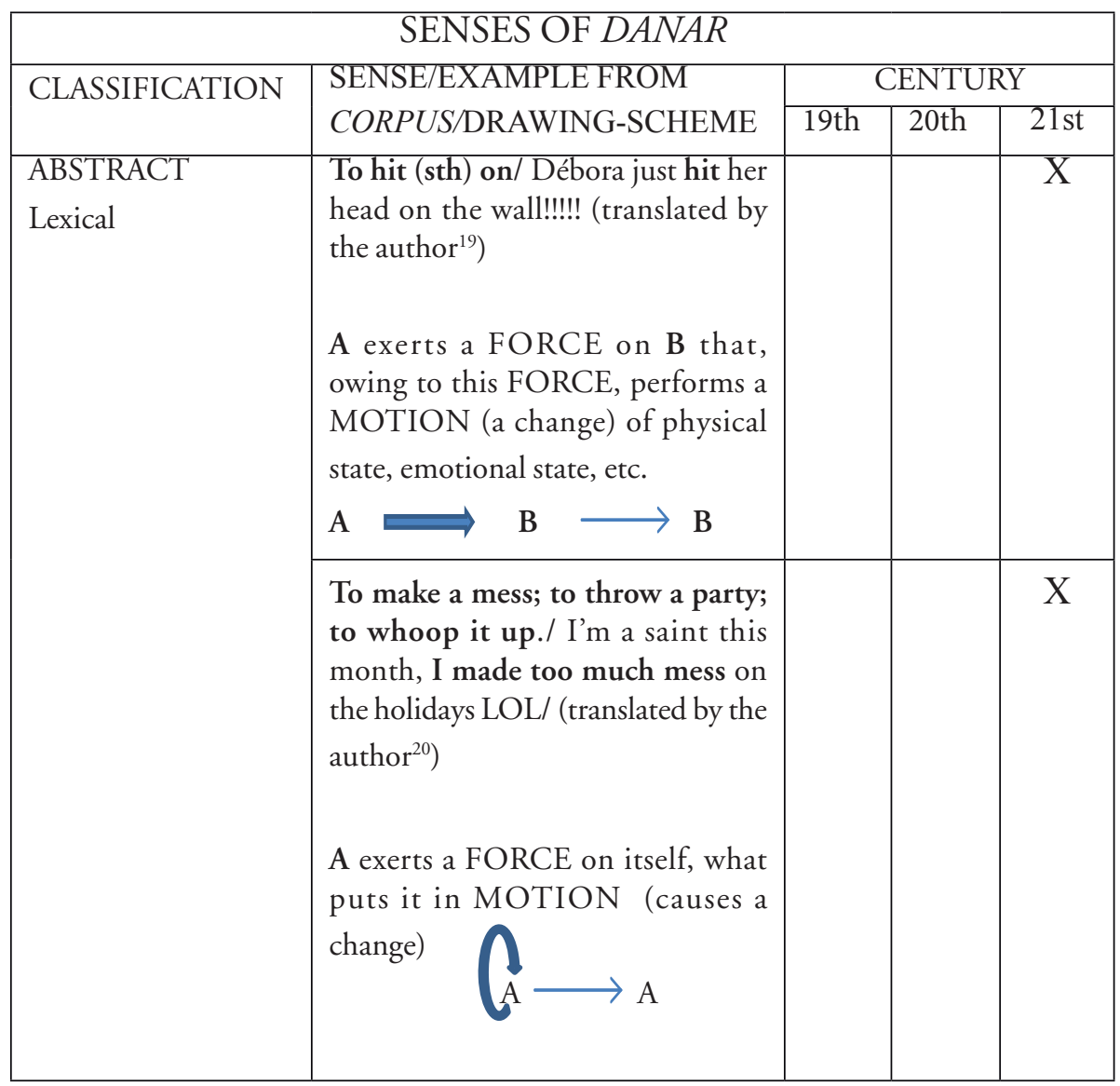

${ }^{19}$ Ruthe. (@_RuthDayane). “Débora acabou de danar a cabeça na parede !!!!!”. 26 Dez 2012, 07: 18 p.m. Tweet.

${ }^{20}$ Gomes, Gabriela. (@GabrielaGoms). "to santa esse mês, me danei dms nas férias kkk”. 10 Jan 2013, 06: 07 p.m. Tweet. 
(continues)

\begin{tabular}{|c|c|c|c|c|}
\hline \multicolumn{5}{|c|}{ SENSES OF $D A N A R$} \\
\hline \multirow{2}{*}{ CLASSIFICATION } & \multirow{2}{*}{$\begin{array}{l}\text { SENSE/EXAMPLE FROM } \\
\text { CORPUS/DRAWING-SCHEME }\end{array}$} & \multicolumn{3}{|c|}{ CENTURY } \\
\hline & & 19th & 20th & $21 \mathrm{st}$ \\
\hline & $\begin{array}{l}\text { To rebuke / Ok, but later I'll chew } \\
\text { him out, I hate it when people put } \\
\text { words in my mouth. (translated by } \\
\text { the author }{ }^{21} \text { ) } \\
\text { A exerts a FORCE on B that, } \\
\text { owing to this FORCE, performs a } \\
\text { MOTION (a change) of physical } \\
\text { state, emotional state, etc. }\end{array}$ & & & $X$ \\
\hline $\begin{array}{l}\text { ABSTRACT } \\
\text { Idiom }\end{array}$ & $\begin{array}{l}\text { To screw yourself: Used to wish } \\
\text { evil upon other person, as if it were } \\
\text { a synonym of the widely known } \\
\text { expression "Go to hell"./ I went on } \\
\text { a ride on my four-wheeler when the } \\
\text { man came complaining that I was } \\
\text { driving at high speed... Go screw } \\
\text { yourself, the four-wheeler is mine. } \\
\text { (translated by the author }{ }^{22} \text { ) } \\
\text { A exerts a FORCE on B that, } \\
\text { owing to this FORCE, performs a } \\
\text { MOTION (a change) of physical } \\
\text { state, emotional state, etc. }\end{array}$ & & X & $\mathrm{X}$ \\
\hline & $\mathbf{A} \longrightarrow \mathbf{B} \longrightarrow \mathbf{B}$ & & & \\
\hline
\end{tabular}

${ }^{21}$ Tami. (@fc_anjolrds2). "poisé, mais depois eu vou danar com ele, odeio que as pessoas coloquem palavras na minha boca”.26 Dez 2012, 01:53 p. m. Tweet.

22 Nathalya. (@nathalyaanunes). "Fui andar de quadri ai o homem veio reclamar que a velocidade tava alta... Vai te danar, o quadriciclo é meu”. 28 Dez 2012, 12: 05 p.m. Tweet. 
(continues)

\begin{tabular}{|c|c|c|c|c|}
\hline \multicolumn{5}{|c|}{ SENSES OF $D A N A R$} \\
\hline \multirow[t]{2}{*}{ CLASSIFICATION } & \multirow{2}{*}{$\begin{array}{l}\text { SENSE/EXAMPLE FROM } \\
\text { CORPUS/DRAWING-SCHEME }\end{array}$} & \multicolumn{3}{|c|}{ CENTURY } \\
\hline & & 19th & 20 th & $21 s t$ \\
\hline $\begin{array}{l}\text { ABSTRACT } \\
\text { Idiom }\end{array}$ & $\begin{array}{l}\text { Que se dane: expression used to } \\
\text { wish evil upon someone, as if it } \\
\text { were a synonym of the widely } \\
\text { known expression "Go to hell". / } \\
\text { @SKYanswers I already gave } \\
\text { them information about this } \\
\text { shit! I want them to go to hell! } \\
\text { INCOMPETENT BASTARDS! } \\
\text { (translated by the author }{ }^{23} \text { ) } \\
\text { A exerts a FORCE on B that, } \\
\text { owing to this FORCE, performs a } \\
\text { MOTION (a change) of physical } \\
\text { state, emotional state, etc. }\end{array}$ & & $\mathrm{X}$ & $\mathrm{X}$ \\
\hline & $\mathrm{A} \longrightarrow \mathrm{B} \longrightarrow \mathrm{B}$ & & & \\
\hline & $\begin{array}{l}\text { To dane it: used to wish evil upon } \\
\text { other person, as if it were a synonym } \\
\text { of the widely known expression } \\
\text { "Go to hell"./ don't like these soap } \\
\text { operas soap opera we have our lives } \\
\text { already so damn all of you who } \\
\text { try to manipulate people minds. } \\
\text { (translated by the author }{ }^{24)} \\
\text { A exerts a FORCE on B that, } \\
\text { owing to this FORCE, performs a } \\
\text { MOTION (a change) of physical } \\
\text { state, emotional state, etc. } \\
\text { A } \longrightarrow \text { B }\end{array}$ & & & $\mathrm{X}$ \\
\hline
\end{tabular}

${ }^{23}$ Pinheiro, Fabio. (@Fabiojsp). “@SKYresponde já informei essa porcaria! Quero que se danem! INCOMPETENTES!”. 09 Jan 2013, 11: 24 p.m. Tweet.

${ }^{24}$ Clube, Santos Futebol. (@santosfc_sfc). "naum gosto de novelas novela ja basta nossa vida entaum danem se vcs q tentam manipular a mente das pessoas". 07 Jan 2013, 04: 04 p.m. Tweet. 
(conclusion)

\begin{tabular}{|c|c|c|c|c|}
\hline \multicolumn{5}{|c|}{ SENSES OF $D A N A R$} \\
\hline \multirow[t]{2}{*}{ CLASSIFICATION } & SENSE/EXAMPLE FROM & \multicolumn{3}{|c|}{ CENTURY } \\
\hline & CORPUS & 19th & 20 th & $21 s t$ \\
\hline GRAMMATICAL & $\begin{array}{l}\mathrm{V} 1_{\text {DANAR }}+(\text { pron })+(\text { prep }) \\
+\mathrm{V} 2_{\text {infinitive }} \text {. Marks the inceptive } \\
\text { aspect cumulated with the idea of } \\
\text { extension of action./ Now when I } \\
\text { watch the movie " } 2012 \text { " I'm gonna } \\
\text { laugh till drop! (translated by the } \\
\text { author }{ }^{25} \text { ) }\end{array}$ & & $\mathrm{X}$ & $\mathrm{X}$ \\
\hline & $\begin{array}{l}\text { There is a MOTION from } \mathrm{A} \text { to } \mathrm{B} \\
\text { owing to a FORCE }\end{array}$ & & & \\
\hline & $\longrightarrow \mathrm{A} \longrightarrow \mathrm{B}$ & & & \\
\hline
\end{tabular}

Source: Collected data

The chart also allows us to observe the expansion of meanings from the three Centuries studied here. Our data show that some of the categories postulated by Lakoff (1987), by Johnson (1987), and by Lakoff \& Johnson (2002) make it evident that most abstract senses of DANAR have dissipated from the more concrete senses, which can be explained by the notions of motion and force, which already existed in the concrete senses.

\section{Conclusion}

Our research has shown that there is a coherence/relation (determined by the imagetic schemes of FORCE and MOTION) between the various senses of the verb $D A N A R$, which confirms the polysemy of this item. The senses of $D A N A R$ are, therefore, metaphorically structured around those two imagetic schemes, which supports the assertion that "whatever the causes that produce change, there must always be some sort of connection, some sort

\footnotetext{
${ }^{25}$ Leticia. (@aawnleeh). “Agora quando eu assistir o filme “2012” vou danar a rir!”. 12 Jan 2013, 12: 11 p.m. Tweet.
} 
of association, between the old meaning and the new one" (ULLMANN, 1964, p. 438).

This work also demonstrates that the construction of V1DANAR + (pron) $+($ prep $)+V 2_{\text {infinitive }}$, considered by many as a very informal structure, and not accepted in certain social standards, is the result of a cognitive metaphorical process that has been scientifically studied and accounted for.

\section{References}

BUENO, F.S. Grande dicionário etimológico-prosódico da língua portuguesa: vocábulos, expressões da lingua geral e cientifica-sinônimos; contribuiçôes do tupiguarani. São Paulo: Ed. Brasilia, 1974.

BYBEE, J. Mechanisms of Change in Grammaticalization: the Role of Frequency. In: BRIAN, Joseph; JANDA, Richard. (Ed.). The handbook of Historical Linguistics. Oxford: Blackwell, 2003. cap. 19, p. 602-623.

COMRIE, B. Aspect: an introduction to the study of verbal aspect and related problems. Cambridge: Cambridge University Press, 1976.

Corpus do Português: 45 million words, 1300s-1900s. Developed by Mark Davies and Michael Ferreira. Presents the Portuguese Language Corpus, with 45 with 45 million words from nearly 57 , texts in Portuguese from the 13th to the 20th century. Available at: <http://www.corpusdoportugues.org>. Retrieved on: Sept. 12, 2011. CUNHA, A.G. Dicionário etimológico da língua portuguesa. 4. ed. Rio de Janeiro: Lexikon: FAPERJ, 2010.

EVANS, V; GREEN, M. Cognitive Linguistics: An Introduction. Edinburgh: Edinburgh University Press; 2006.

GIBBS JR, R. W; MATLOCK, T. Metaphor, imagination, and simulation: Psycholinguistic evidence. In: GIBBS JR, R. W (Ed.). The Cambridge handbook of metaphor and thought. New York: Cambridge University Press, 2008. p.161-176. GONÇALVES, S.C.L et al. Introdução à gramaticalização. São Paulo: Parábola Editorial, 2007.

HEINE, B; CLAUDI, U; HÜNNEMEYER, F. From Cognition to Grammar: Evidences from African Languages. In: TRAUGOTT, E. C.; HEINE, B. (Ed.) Approches to Grammaticalization. Amsterdam: John Benjamins, 1991b. p. 149-188. HOPPER, P. On some priciples of grammaticization. In: TRAUGOTT, E. C; HEINE, B. (Ed.). Approaches to grammaticalization. Amsterdan: Jonhn Benjamins, 1991, p. 17-36.

HOUAISS, A.; VILLAR, M. S. Dicionário Houaiss da Lingua Portuguesa. Rio de Janeiro: Objetiva, 2001. 
JOHNSON, M. The Body in The Mind: The Bodily Basis of Meaning, Imagination and Reason. Chicago: University of Chicago Press. 1987.

KÖVECSES, Z. Metaphor: A Practical Introduction. 2. ed. New York: Oxford University Press, 2010.

LAKOFF, G. Women, Fire and Dangerous Things: What Categories Reveal about the Mind. Chicago: University of Chicago Press, 1987.

LAKOFF, G. JOHNSON, Mark. Metáforas da vida cotidiana. (Translated by

Mara Sophia Zanotto). Campinas: Mercado de Letras; São Paulo: Educ, 2002.

OLIVEIRA, R.P. Semântica. In.: MUSSALIM, F.; BENTES, A.C. (Ed.). Introdução à lingüistica: domínios e fronteiras. São Paulo: Cortez, 2001. v. 2, cap. 1, pp. 17-46. PAULA, T. F. Estudo do processo de gramaticalização do verbo DANAR para marcação de aspecto no Português Brasileiro. 2014. $92 \mathrm{f}$. Thesis (Masters in Linguistics) Universidade Federal de Minas Gerais, College of Letters, Belo Horizonte, 2014. SIGILIANO, N.S. O telefone tocô eu peguei e: quem tá falano? - A polissemia do verbo PEGAR. 2008. 133 f. Thesis (Masters in Letters - Linguistics) - Universidade Federal de Juiz de Fora (UFJF), College of Letters, Juiz de Fora, 2008.

SIGILIANO, N.S. Persistência e extensão na construção inceptiva em [v1fin (prep) v2inf] do português. Letras \& Letras, Uberlândia, v. 27, p. 127-142, 2011.

SIGILIANO, N. S. Evidências translinguísticas da metáfora de movimento na construção de aspecto inceptivo. Linguistica, Rio de Janeiro, v. 8, p. 33-48, 2012.

SILVA, A. S. O sentido múltiplo: polissemia, semântica e cognição. In: FELTES, Heloísa Pedroso de Moraes (Ed.), Produção de Sentido. Estudos transdisciplinares. São Paulo, Caxias do Sul: Editora a Universidade de Caxias do Sul, 2003, p. 91-115.

TRAVAGLIA, L. C. Uma gramaticalização em cadeia para indicação de aspectos. In.: VITRAL, L; COELHO, S. (Ed.). Estudos de processos de gramaticalização em português: metodologias e aplicaçôes. Campinas: Mercado de Letras, 2010.chapter IV, p. 105-137.

Twitter. Developed by Jack Dorsey, Evan Williams, Biz Stone, and Noah Glass, 2006. Social network and server for microblogging, which allows users to send and receive personal updates from other contacts in texts of up to 140 characters, known as tweets. Available at: <https://www.twitter.com/>. Retrieved on Dec. 31, 2012. ULLMANN, S. Semântica; uma introdução à ciência do significado (Translated by J.A. Osório Mateus). 5a ed. Lisboa: Fundação Calouste Gulbenkian, 1964.

Data de submissão: 04/08/2014. Data de aprovação: 06/01/2015. 
